\title{
Prospects for using combined (traditional and physical-chemical) mining technologies in the development of large gold-copper ore deposits
}

\author{
Artur Sekisov ${ }^{1 *}$ and Slava Korolev ${ }^{2}$ \\ ${ }^{1}$ Mining Institute FEB RAS, 51 Turgenev st., Khabarovsk, 680000, Russia; \\ ${ }^{2}$ Advanced Recovery, Advanced Recovery, Cal. USA
}

\begin{abstract}
Annotation. The article deals with the problems of development of large gold-copper ore deposits, which have prospects for the development of mining and processing complexes based on them, which produce refined metals as final products. The article substantiates the feasibility of using combined traditional and physical-chemical geotechnologies in the development of these deposits, including geotechnologies in mining, using innovative processes of activation of heap and underground leaching of copper, fine and dispersed gold from complex ores. At the initial stage of development of the large deposits of complex ores, in parallel with traditional schemes open-pit mining and ore processing at the processing plant, it is advisable to use the activation heap leaching of valuable components from poor and refractory ores and flotation tailings from ordinary and rich ore. At the second stage, when switching to the underground method of field development, it is proposed to use block- hole leaching with explosion-injection ore preparation with combination with it. The proposed schemes for combined development of complex gold-copper ore and copper-ore deposits with precious metal mineralization are based on data obtained during many years of experimental research and pilot tests.

Keywords Complex ore deposits, mining, geotechnologies in mining, heap and underground leaching, block-hole leaching, explosion-injection preparation of ores for leaching, active solutions for leaching, peroxidecarbonate solution, chloride-carbonate solution.
\end{abstract}

\section{Introduction}

The large gold-copper ore and copper ore deposits with precious -metal mineralization are explore around the world. The efficiency of development of such large-scale deposits of complex ores, due to the significant depth of ore bodies with various morphology, spatial variability of geometric and mater-structural parameters, is determined by the establishment of a rational area of use of open pit, underground as well as physicochemical geotechnologies. Moreover, physicochemical geotechnologies can be used both in combination with open pit and underground mining. In the zone of open pit mining

* Corresponding author: sekisovag@mail.ru 
operations, leaching of valuable components from can be used, and leaching of poor and/or refractory ore will be processed by heap and/or vat leaching. For several decades, underground and open pit leaching has been used in the uranium and copper ore industries in many countries, including the Russian Federation, but the use of these physicochemical geotechnologies in the development of large-scale deposits of complex gold-copper ores has a number of features associated with significant differences in the physicochemical properties of ore minerals, high density of ores. But the main factor significantly limiting the possibility of using physicochemical geotechnologies in the development of the mining under consideration because of precious metals are located in ores in the complex and cluster forms. In order to achieve the degree of ore crushing required for leaching in the process of explosive preparation and the formation of a developed network of microcracks and pores in them, it is required to find new effective types of explosive charges. In addition, it is necessary to solve problems related to the consistent or combined use of various complexforming agents for leaching copper, silver and gold and establishing effective physical and chemical parameters of leaching solution (pH, ORP).

\section{Objects, materials and research methods}

Considered as the main objects of research, the Udokanskoye deposit of copper sandstones, the Malmyzhskoye copper-porphir deposit, the Darasunskoye gold-copper ore deposit, have a significantly different mineral composition of both primary ores and ores of oxidation zones. The materials used for experiments on agitation and percolation leaching of copper, encapsulated and chemically bound dispersed gold, include: ore of the oxidation zone of the Malmyzhskoye deposit, mixed and primary ores of the Udokan deposit, primary ores of the quartz-sulfide formation of the Darasunskoye deposit and tailings of the ore flotation.

The ores of the oxidation zone of the Malmyzhskoye deposit are ore-bearing metasomatized diorite porphyrites with a copper content below the level $0.3 \%$, but with local areas characterized by a gold content of 0.5 to $1.2 \mathrm{~g} / \mathrm{t}$. With selective extraction of oxidized ores with such a gold content, their cost-effective processing is possible using heap leaching technology. Experiments conducted at the IGD DVO RAS made it possible to establish that the most effective method of processing such ores is their heap preoxidation with an electro-fotoactive sulfuric acid-peroxide solution, followed by leaching gold and accompanying silver with an active chloride-hypochlorite solution. This method provides a high (more than 90\%) gold recovery with minimal non-productive consumption of reagents for the dissolution of iron and copper. Since the bulk of the reserves of the Udokan and Malmyzh deposits are represented by primary sulfide and quartz-sulfide ores, the main studies were carried out on the leaching of copper, gold and silver from such ores. Moreover, since copper and associated noble metals of primary ores are located in them in various mineral and geochemical forms, leaching experiments were carried out using several reagent schemes. A combined scheme including nitrite-peroxide pre-oxidation followed by percolation leaching of valuable components with an active hypochlorite-chloride solution was successfully tested for primary diorite-porphyrite ores of the Malmyzhsky Deposit.Unlike the Malmyzhskoye deposit, the ores of the oxidation zone of the Udokan deposit, are mixed with a variable ratio of oxidized minerals of various composition of copper and iron sulfides. The main ore minerals of the oxidation zone of the Udokan deposit are hydroxy-sulfates (brocantite, to a lesser extent antlerite) and carbonatehydroxide (malachite, azurite) are relatively quickly leached by an acidified sulfuric acid solution. In conducted experiments on percolation oxidation (preoxidation) - saturation of mixed ores of the Udokan deposit, preoxidation with an electro-fotoactive sulfuric acidperoxide solution was also used, followed by leaching of gold and accompanying silver with an active chloride-hypochlorite solution. The model of the combined process of 
activation oxidation of bornite-chalcosine ores of the Udokan deposit with accompanying chalcopyrite and leaching of copper from them can be represented by the following reaction system:

1. Oxidation of iron and partial oxidation of copper in bornite by peroxide complexes:

$$
\mathrm{Cu}_{5} \mathrm{FeS}_{4}+\mathrm{H}_{2} \mathrm{O}_{2} * n \mathrm{H}_{2} \mathrm{O}=\mathrm{FeSO}_{4}+\mathrm{CuSO}_{4}+2 \mathrm{Cu}_{2} \mathrm{~S}+14 \mathrm{H}^{+}(n-6) \mathrm{H}_{2} \mathrm{O} \text {. }
$$

2. Dissolution of copper, which is part of chalcosine sulfuric acid-peroxide complexes and the formation of iron oxide sulfate:

$$
\begin{gathered}
\mathrm{Cu}_{2} \mathrm{~S}+2\left(\mathrm{H}_{2} \mathrm{O}_{2}\right) * \mathrm{O}_{2} * n \mathrm{H}_{2} \mathrm{O}+\mathrm{H}_{2} \mathrm{SO}_{4}=2 \mathrm{CuSO}_{4}+\mathrm{H}_{2} \mathrm{SO}_{4}+2 \mathrm{H}^{+*}(n+2) \mathrm{H}_{2} \mathrm{O} \\
2 \mathrm{FeSO}_{4}+\left(\mathrm{H}_{2} \mathrm{O}_{2}\right) * n \mathrm{H}_{2} \mathrm{O}+\mathrm{H}_{2} \mathrm{SO}_{4}=\mathrm{Fe}_{2}\left(\mathrm{SO}_{4}\right)_{3}+(n+2) \mathrm{H}_{2} \mathrm{O}
\end{gathered}
$$

3. leaching of copper, which is part of chalcopyrite, with hydrochloric acid with the participation of iron oxide sulfate:

\section{$\mathrm{CuFeS}_{2}+8 \mathrm{HClO}^{*}+\mathrm{Fe}^{3+*} 6 \mathrm{H}_{2} \mathrm{O}=\mathrm{CuCl}_{2}+2 \mathrm{FeCl}_{3}+2 \mathrm{H}_{2} \mathrm{SO}_{4}+6 \mathrm{H}_{2} \mathrm{O} * 4 \mathrm{H}^{+}$.}

To extract silver, at the final stage, the ore was re-oxidized with an electro-fotoactivated sulfuric acid-peroxide solution with the addition of sodium nitrite and leaching with an active peroxide-nitric acid solution. There is no oxidation zone at the Darasunskoye deposit, therefore, experiments for this object were carried out only on primary ores. Darasunskoye deposit is more correctly considered as deposit cluster , including Darasun itself, a complex of vein and a large brecchia ore body, as well as two small vein deposits: Teremki and Talatuy. The vein ores of the Darasunskoye deposit have a complex mineral composition, contain from 6 to $10 \%$ sulfides and sulfoarsenides, among which pyrite, arsenopyrite, chalcopyrite and pyrrotine. Galenite and sphalerite are noted in smaller quantities. Chemically bound dispersed gold is concentrated in almost all sulfide and sulfosalic minerals, and in chalcopyrite its content reaches more than $100 \mathrm{~g} / \mathrm{t}$. In this connection, experiments were conducted on nitrite-peroxide pre-oxidation followed by percolation leaching of gold and copper from ores and explosion-injection leaching of gold from the tailings of flotation of ores of the Darasun Deposit, which showed the possibility of extracting such forms of gold using physical and chemical geotechnologies. The brecchium type of ore, despite the relatively low gold content, has significant reserves with conditioned copper content. Exploratory brecchias of the Darasunskoye deposit with subvertical occurrence and significant size of the ore body can be worked out in a combined way. The upper part can be worked out by an open pit method followed by heap leaching of valuable components of the main part of the produced poor and ordinary ore and processing of rich ores in a plant. The lower- part with method, combine the traditional extraction of rich ores with subsequent laying of chambers and underground percolation leaching of gold and copper from ore pillars and laying, a component of which is the tailings of flotation of rich ores. Underground percolation leaching of gold and copper block or block-hole follow for nitrite-peroxide pre-oxidation followed.

\section{Results and discussion.}

Experiments on leaching copper, silver and gold from primary sulfide Udokan ores of the bornite-chalcosine paragenesis, were carried out on a large-scale sample (average size of individuals of the order of $30 \mathrm{~cm}$ ) weighing $10.5 \mathrm{~kg}$. The content of valuable components in the sample was: copper $17.82 \%$, silver $147 \mathrm{~g} / \mathrm{t}$, gold $0.28 \mathrm{~g} / \mathrm{t}$. Leaching of valuable components was carried out in 3 stages with active solutions treated in an electrofotochemical reactor. The final recovery of copper into solutions was $82.6 \%$, which is comparable to the indicator according to the traditional scheme: ore mining - flotation hydrometallurgical treatment of flotation concentrate. Silver extraction was $61.3 \%$, gold $64.3 \%$. The total percolation leaching time was 58 days. 
For the oxidation of primary ores containing copper mainly in the composition of chalcopyrite (Malmyzhskoye and Darasunskoye deposits), a nitrous-sulfuric acid-peroxide complex was used, formed by preparing solutions of initial reagents with certain parameters and in a certain sequence in an electrofotochemical reactor. Subsequent leaching of copper and silver with chloride-hypochlorite solutions ensured the extraction of these metals by 55-73 and 68-87\%, respectively. The extraction of gold from the ore sample, prepared by explosion injections, followed by leaching with active chloride-peroxide solutions, carried out in pulsation-static regime, ultimately amounted to more than $80 \%$ in 3 days. Thus, the use of activation leaching will significantly increase the efficiency and safety of the development of large complex copper-gold deposits.

\section{List of references}

1. O. S. Bryukhovetsky, A. G. Sekisov, A. Yu. Lavrov, A.V. Rasskazova, Mining journal, 2, 48-52 (2020)

2. E. Cepeda-Perez, N. de Jonge, Micron, 117, 68-75 (2019)

3. M. Xu, M. G. Suleiman, H. sun, B. Pelaz, N. - Feliu, J. Parak, S. Yu. Liu, ACS nano, 12(10), 10104-10113 (2018)

4. A.V. Rasskazova, XXIX international Congress on mineral processing (IMPC 2018), Moscow, Russia, September 17-21, 2018, 4093-4098 (2018)

5. L. I. Lunev, Research Methods for substantiating underground systems of metal leaching (Moscow: MGRI Publishing house, 1978)

6. V. I. Golik, Gorny Zhurnal, 2, 18-22 (2009)

7. P. J. Van Staden, J. Petersen, Engineering of mineral resources, 128, 202-214 (2018)

8. A. G. Sekisov, A.V. Rasskazova, Pat. 2647961 Russian Federation, IPC S22B 11/00, 3/04.; no. 2017120462; declared 09.06.2017; published 21.03.2018

9. P. L. Breuer, X. Dai, M. I. Jeffrey, Hydrometallurgy, 78(3-4), 156-165 (2005)

10 H. R. Watling, Hydrometallurgy, 140, 163-180 (2013)

11. Shevkun E. B., Miroshnikov V. I., Cherednikov S. V., Leonenko N. A. Pat. 2647961

Russian Federation, IPC F42D3 / 04 F42D5/05, publ. 20.01.1999 